\title{
Primary CTL response magnitude in mice is determined by the extent of naive T cell recruitment and subsequent clonal expansion
}

\author{
Nicole L. La Gruta, ${ }^{1}$ William T. Rothwell, ${ }^{1}$ Tania Cukalac, ${ }^{1}$ Natasha G. Swan, ${ }^{1}$ Sophie A. Valkenburg, ${ }^{1}$
} Katherine Kedzierska, ${ }^{1}$ Paul G. Thomas, ${ }^{2}$ Peter C. Doherty, ${ }^{1,2}$ and Stephen J. Turner ${ }^{1}$

1Department of Microbiology and Immunology, University of Melbourne, Parkville, Victoria, Australia.

2Department of Immunology, St. Jude Children's Research Hospital, Memphis, Tennessee, USA.

\begin{abstract}
$\mathrm{CD8}^{+} \mathrm{T}$ cell responses to viral infection are characterized by the emergence of dominant and subdominant CTL populations. The immunodominance hierarchies of these populations are highly reproducible for any given spectrum of virus-induced peptide-MHCI complexes and are likely determined by multiple factors. Recent studies demonstrate a direct correlation between naive epitope-specific $\mathrm{CD8}^{+} \mathrm{T}$ cell precursor (CTLP) frequency and the magnitude of the response after antigen challenge. Thus, the number of available precursors in the naive pool has emerged as a key predictor of immunodominance. In contrast to this, we report here no consistent relationship between CTLp frequency and the subsequent magnitude of the immune response for 4 influenza virus-derived epitopes following intranasal infection of mice with influenza A virus. Rather, the characteristic, antigen-driven $T$ cell immunodominance hierarchy was determined by the extent of recruitment from the available pool of epitope-specific precursors and the duration of their continued expansion over the course of the infection. These findings suggest possibilities for enhancing protective immune memory by maximizing both the size and diversity of typically subdominant $T$ cell responses through rational vaccine design.
\end{abstract}

\section{Introduction}

Despite pathogen complexity, virus-specific $\mathrm{CD}^{+} \mathrm{T}$ cell immunity is characterized by clonal expansions of $\mathrm{CD}^{+} \mathrm{T}$ cell precursors (CTLps) specific for a limited range of possible peptides complexed with class I MHC molecules (pMHCI) (1). Furthermore, the overall CTL response to any given spectrum of virus-induced pMHCI epitopes falls into a highly reproducible immunodominance hierarchy (1). While much of the research focus has been on the more readily analyzed large, dominant CTL populations, it has become apparent that subdominant responses can also play a key role in immunity (2), particularly in situations where a diverse array of "minor" epitopes is being recognized $(2,3)$ or there is the potential for mutational escape from immune control. Given that protection and recovery from any given virus infection is likely to depend on the overall breadth and extent of immunity (2-5), developing a better understanding of factors that determine CTL immune magnitude is essential, particularly for the design of novel vaccination and immunotherapy strategies that make optimal use of subdominant CTL responses.

Both virus and host effects are thought to determine immunodominance hierarchies following primary virus challenge. These effects can be grouped into 2 broad categories: (a) those affecting pMHCI abundance on the surface of APCs and (b) the number, recruitment, and proliferative capacity of naive epitope-specific CTLps that can engage in the response $(1,6)$. The latter set of parameters has been especially difficult to measure, particularly when the naive CTLps are physiologically generated "endogenous" responders rather than TCR-Tg precursors (7-13).

Recently, the development of a practicable enrichment approach that uses pMHC tetramers has made it possible to measure the

Conflict of interest: The authors have declared that no conflict of interest exists. Citation for this article: J Clin Invest. 2010;120(6):1885-1894. doi:10.1172/JCI41538. naive CTLp side of the equation for physiological immune responses (14). Studies using this new approach have demonstrated a correlation between naive CTLp frequencies and immune magnitude for a range of viral and nonviral epitopes $(15,16)$. The focus to date has, however, been on the more prominent pMHCI-specific CTL sets, with the implication being that all the naive CTLps are recruited into the immune response. This is also the conclusion of a recent study that tracked recruitment of genetically tagged TCR Tg T cells after transfer (17). But is that indeed the case in a polyclonal $\mathrm{T}$ cell response to viral infection, and is CTLp prevalence the overarching determinant of CTL response magnitude?

The i.n. infection of C57BL/6J (B6) mice results in CTL responses directed against a range of pMHCI determinants that fall into a characteristic immunodominance hierarchy (18). The immunodominant CTL populations are specific for $\mathrm{PMHCI}$ epitopes derived from the viral nucleoprotein $\left(\mathrm{NP}_{366}\right)$ (19) and acid polymerase $\left(\mathrm{PA}_{224}\right)(20)$, while 2 of the subdominant responses are directed at peptides from the basic polymerase subunit 1 frameshift 2 protein (PB1-F2 ${ }_{62}$; ref. 21) and nonstructural protein 2 (NS2 ${ }_{114}$; ref. 22). The reproducibility of this response hierarchy provides a robust model for analyzing the basis of immunodominance.

Using a combination of tetramer enrichment, single-cell TCR sequencing, and BrdU labeling, we demonstrate that subdominant response status is unrelated to naive CTLp frequency but is a consequence of inefficient CTLp recruitment and/or expansion early after infection. As such, subdominant responses represent a potentially underutilized pool of CTL that may be efficiently recruited into the immune compartment with appropriate vaccination strategies.

\section{Results}

Naive CTLp frequencies and the immunodominance bierarchy. The characteristic influenza-specific immunodominance hierarchy in virus-infected $\mathrm{B} 6$ mice is shown in Figure 1A for the $\mathrm{D}^{\mathrm{b}} \mathrm{PA}_{224^{-}}$, 
A

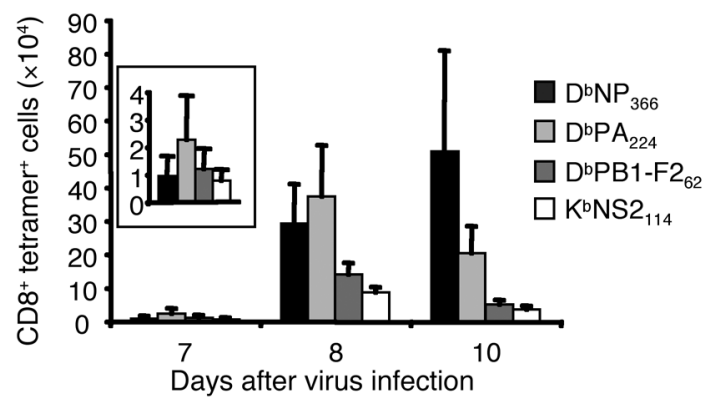

4

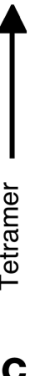

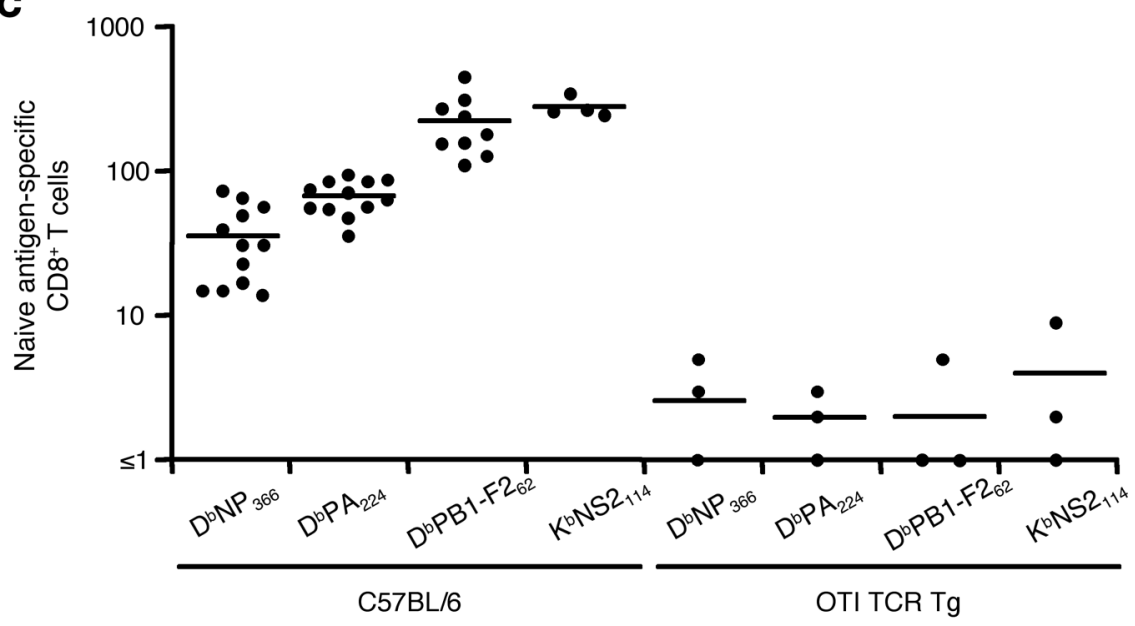

Figure 1

Influenza epitope-specific immune magnitudes do not correlate with naive precursor frequencies. (A) Naive B6 mice were infected i.n. with influenza virus and spleens harvested 7,8 , or 10 days later for analysis of $\mathrm{CD}^{+} \mathrm{D}^{\mathrm{b}} \mathrm{NP}_{366^{-}}, \mathrm{D}^{\mathrm{b} P \mathrm{PA}_{22}}$, $\mathrm{D}^{\mathrm{b} P B 1-\mathrm{F}} 2_{62}-$, and $\mathrm{K}^{\mathrm{b} N S} 2_{114}$-specific $T$ cell responses. Shown are the mean total splenic numbers of CD8+tetramer ${ }^{+}$cells for $4-5$ mice \pm SD. Results are representative of 2 independent experiments. (B) Representative dot plots of all $\mathrm{D}^{\mathrm{b}} \mathrm{NP}_{366^{-}}, \mathrm{D}^{\mathrm{b}} \mathrm{PA}_{224^{-}}$, D $\mathrm{D}^{\mathrm{b}} \mathrm{PB} 1-\mathrm{F} 2_{62-}$, and $\mathrm{K}^{\mathrm{b} N S 2} 2_{114}$-specific CD8 ${ }^{+} \mathrm{T}$ cells detected from spleen and all major LNs of naive mice using a magnetic enrichment and staining procedure (as described in Methods). Values indicate the number of tetramer+CD62 $\mathrm{L}^{\text {hi }}$ cells within the gate shown. (C) Total numbers of epitope-specific CD8 ${ }^{+}$cells identified from spleen and all major LNs in naive $\mathrm{B} 6$ mice or OTI TCR Tg mice. Symbols represent data from individual mice obtained in 4 independent experiments. Horizontal bars indicate mean values.
$\mathrm{D}^{\mathrm{b}} \mathrm{NP}_{366^{-}}, \mathrm{D}^{\mathrm{b}} \mathrm{PB} 1-\mathrm{F} 2{ }_{62-}$, and $\mathrm{K}^{\mathrm{b}} \mathrm{NS} 2_{114^{-}}$specific CD8 ${ }^{+} \mathrm{CTL}$ populations. As described previously $(23,24)$, the $\mathrm{D}^{\mathrm{b}} \mathrm{PA}_{224}$-specific $\mathrm{T}$ cells are at highest prevalence early (days 7 and 8), with the $\mathrm{D}^{\mathrm{b}} \mathrm{NP}_{366^{-}}$ specific CTLs becoming more prominent by day 10 after infection and the $\mathrm{D}^{\mathrm{b}} \mathrm{PB} 1-\mathrm{F} 2_{62^{-}}$and $\mathrm{K}^{\mathrm{b}} \mathrm{NS} 2_{114^{-}}$-specific sets remaining subdominant throughout (ref. 25 and Figure 1A). Importantly, all 4 tetramers detect responding CTLs at frequencies equivalent to those determined for peptide-stimulated $\mathrm{T}$ cell populations by the intracellular cytokine staining (ICS) assay (Supplemental Figure 1; supplemental material available online with this article; doi:10.1172/JCI41538DS1). There is thus no substantial divergence in binding efficiency or sensitivity that might be thought to skew the results for the different tetramers.

The tetramer enrichment protocol (14) was used to detect the 4 naive (CD62L hi) CTLp populations in pooled spleen and LNs from individual, uninfected B6 mice. Shown are the total numbers of epitope-specific cells identified from spleen and all major LNs (Figure 1, B and C), with similar relative values being obtained when these numbers were calculated as frequencies per $10^{6} \mathrm{CD}^{+} \mathrm{T}$ cells (Supplemental Figure 2). Uninfected B6 mice expressing a Tg TCR (OTI) specific for the ovalbumin 257-264 epitope were used as controls. Minimal evidence of tetramer binding was found for 3 separate OTI TCR Tg samples, with the mean counts being less than 4 for all the pMHCI epitopes (Figure 1C). The average number of naive CD8 ${ }^{+} \mathrm{D}^{\mathrm{b}} \mathrm{PA}_{224}{ }^{+} \mathrm{CTLps}$ was 2 -fold larger $(P<0.005)$ than the $\mathrm{CD}^{+} \mathrm{D}^{\mathrm{b}} \mathrm{NP}_{366}{ }^{+}$set $(68 \pm 18$ compared with $36 \pm 21$ ) (Figure $1 \mathrm{C}$ ), confirming previous, indirect estimates of naive $\mathrm{D}^{\mathrm{b}} \mathrm{NP}_{366^{-}}$and $\mathrm{D}^{\mathrm{b}} \mathrm{PA}_{224^{-}}$specific precursor prevalence $(10,26,27)$. Thus, we would conclude that the relative magnitudes and kinetics of the immune $\mathrm{CD} 8^{+} \mathrm{D}^{\mathrm{b}} \mathrm{NP}_{366}{ }^{+}$and $\mathrm{CD}^{+} \mathrm{D}^{\mathrm{b}} \mathrm{PA}_{224}{ }^{+} \mathrm{CTL}$ responses (Figure $1 \mathrm{~A}$ ) are, at least in the initial phase after virus challenge, indeed determined by the naive CTLp frequency (Figure 1C). However, no comparable correlation was apparent for the 2 subdominant epitopes, $D^{\text {b PB } 1-F 2 ~} 62$ and $\mathrm{K}^{\mathrm{b} N S} 2_{114}$. The mean numbers of $\mathrm{D}^{\mathrm{b} P B} 1-\mathrm{F} 2_{62^{-}}(225 \pm 110)$ and $\mathrm{K}^{\mathrm{b} N S} 2_{114}$-specific $(282 \pm 46)$ CTLps were significantly higher than those found for either $\mathrm{D}^{\mathrm{b}} \mathrm{NP}_{366}$ or $\mathrm{D}^{\mathrm{b}} \mathrm{PA}_{224}(P<0.0001)$ (Figure 1, B and C), establishing for the first time that there can be a substantial disconnect between naive CTLp frequency and immune magnitude after infection. 


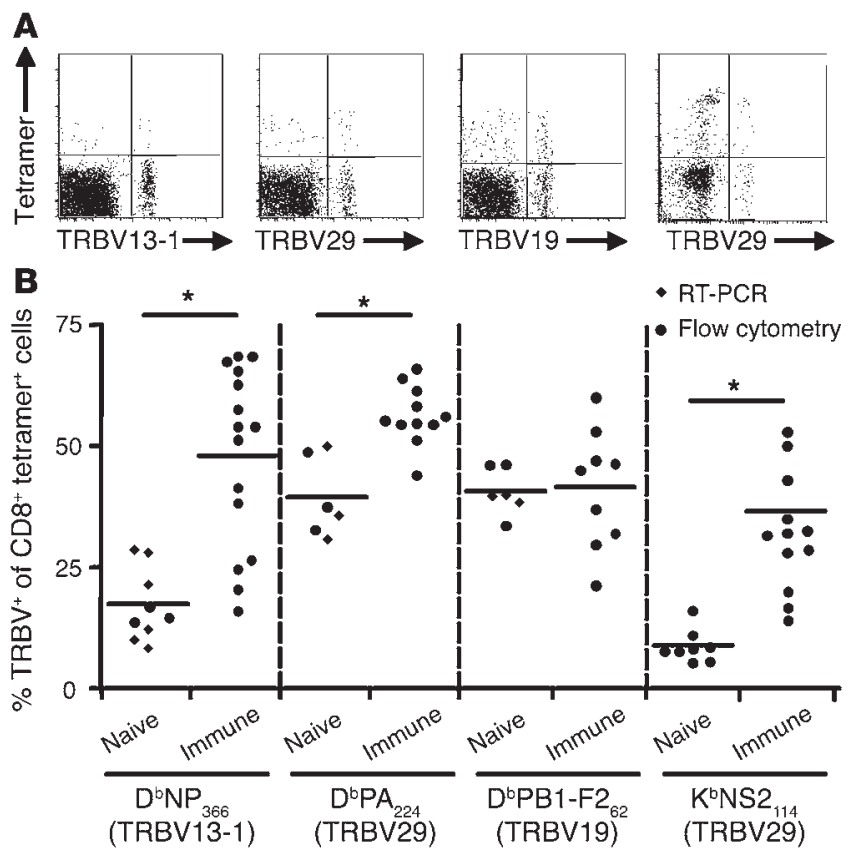

Evaluation of CTLp recruitment by TCR V $\beta$ phenotyping. A possible explanation for this discrepancy between precursor frequency and immune magnitude for immunodominant and subdominant CTL populations is that there are differential profiles of recruitment from the various naive CTLp pools, which may be illuminated by the analysis of TCR usage in naive and immune T cell repertoires. The TCR is an $\alpha \beta$-heterodimer with each chain encoded by somatic gene segments that recombine during $\mathrm{T}$ cell development. Multiple variable $(\mathrm{V})$, junctional $(\mathrm{J})$, and constant $(\mathrm{C})$ gene segments can combine to form the TCR- $\alpha$ chains, while multiple $V$, diversity (D), $\mathrm{J}$, and $\mathrm{C}$ segments encode for the TCR- $\beta$ chains. The TCR- $\alpha$ and $-\beta$ chains have 3 regions of hypervariability, complementarity determining regions (CDR) 1, 2, and 3 , which form the antigen-binding site. The CDR1 and CDR2 loops are encoded by the germline $\mathrm{V}$ gene segment, while the CDR3 loop is positioned at the junction of the $V(D) J$ segments (28). Diversity within the TCR repertoire is generated via (a) different VJ or VDJ gene segment combinations; (b) pairing of different TCR- $\alpha$ and $-\beta$ chains; (c) imprecise joining of gene segments; and (d) the addition of nontemplate encoded nucleotides at $\mathrm{V}(\mathrm{D}) \mathrm{J}$ junctions. Given that most of the observed TCR diversity results from imprecise joining of gene segments and the addition of nontemplate encoded nucleotides (29), TCR diversity is heavily focused toward the CDR3 regions. These loops also mediate significant contacts with the peptide, so the analysis of CDR3 sequences can be thought to reflect the fine specificity of T cells $(25,30,31)$. Considerable efforts have been made previously to define profiles of TCR V $\beta$ (TRBV) usage in the $\mathrm{D}^{\mathrm{b}} \mathrm{NP}_{366^{-}}$, $\mathrm{D}^{\mathrm{b}} \mathrm{PA}_{224^{-}}$, and $\mathrm{D}^{\mathrm{b}} \mathrm{PB} 1-\mathrm{F} 22_{62}$-specific immune repertoires, first by $\mathrm{mAb}$ staining, then by CDR3 $\beta$ sequencing $(10,25)$. The TRBVs (IMGT nomenclature) (32) that are most prominent in these antigen-driven responses (TRBV13-1 for $\mathrm{D}^{\mathrm{b}} \mathrm{NP}_{366}$, ref. 33; TRBV29 for $\mathrm{D}^{\mathrm{b}} \mathrm{PA}_{224}$, ref. 34; TRBV19 for $\mathrm{D}^{\mathrm{b}} \mathrm{PB} 1-\mathrm{F} 2{ }_{62}$, ref. 25 ; and TRBV29 for $\mathrm{K}^{\mathrm{b} N S} 2_{114}$; Figure $2 \mathrm{~B}$ ), were also detected at high prevalence in the naive TCR sets (Figure 2, A and B). The substantial finding from this analysis, however, was that usage of the dominant TRBV in the $\mathrm{D}^{\mathrm{b}} \mathrm{NP}_{366^{-}}, \mathrm{D}^{\mathrm{b}} \mathrm{PA}_{224^{-}}$, and $\mathrm{K}^{\mathrm{b} N S} 2_{114^{-}}$-specific repertoires was signifi-

\section{Figure 2}

Preferred TRBV usage in naive and immune epitope-specific CD8 ${ }^{+} \mathrm{T}$ cell populations. (A) Representative dot plots of tetramer versus specific TRBV for CD8 ${ }^{+}$cells isolated from spleen and all major LNs of naive B6 mice after enrichment with the indicated tetramers. (B) Proportion of tetramer ${ }^{+} \mathrm{CD} 8{ }^{+}$cells expressing the dominant TRBV in naive or immune B6 mice, as identified by flow cytometry (circles) or by single-cell RT-PCR for CD8 and TRBV (diamonds). Symbols represent data from individual mice obtained in at least 2 independent experiments.

cantly increased $(P<0.0005)$ in the immune relative to the naive populations, while this was not seen for $\mathrm{D}^{\mathrm{b}} \mathrm{PB} 1-\mathrm{F} 2_{62}$ (Figure $2 \mathrm{~B}$ ). These data indicate that $\mathrm{D}^{\mathrm{b}} \mathrm{NP}_{366}, \mathrm{D}^{\mathrm{b}} \mathrm{PA}_{224}$, and $\mathrm{K}^{\mathrm{b}} \mathrm{NS} 2_{114}$ are selectively recruiting or expanding $\mathrm{T}$ cell clonotypes from the TRBV13-1+ and TRBV29+ ${ }^{+}$populations, respectively.

Clonotype usage in the naive and immune TCR repertoires. We next sequenced the TCR CDR3 $\beta$ regions from individually sorted, naive $\mathrm{CD}^{+}$tetramer ${ }^{+} \mathrm{T}$ cells within the dominant TRBV sets for $\mathrm{D}^{\mathrm{b}} \mathrm{NP}_{366^{-}}, \mathrm{D}^{\mathrm{b}} \mathrm{PA}_{224^{-}}$, and $\mathrm{D}^{\mathrm{b}} \mathrm{PB} 1-\mathrm{F} 262$ and compared them with those found previously in immune CTLs (refs. 25, 30, and 31; Table 1 and Supplemental Tables 1 and 2). Prior to developing the capacity to isolate naive CTLps, we used the number of TCR- $\beta$ aa clonotypes within epitope-specific CTL populations after antigen-driven expansion to infer naive CTLp frequency (10). We thus reasoned that comparison of TCR- $\beta$ clonotypic usage within the naive and immune repertoires would provide a reliable measure of naive CTLp recruitment into the immune response. Indeed, the same modal CDR3 $\beta$ length (data not shown) and preferred TRBJ (Supplemental Figure 3) gene segment usage was found in both the naive and immune repertoires $(25,30,31)$. This consistency of TCR usage for naive and immune T cells was further confirmed by analysis of the CDR3 $\beta$ aa sequences (Table 1 and Supplemental Tables 1 and 2). The relatively "public" TRBV13-1+ $\mathrm{D}^{\mathrm{b}} \mathrm{NP}_{366}$-specific immune repertoire is characterized by the use of a limited number of clonotypes that tend to be shared among different individuals $(30,35)$. In contrast, the "private" TRBV29+ $\mathrm{D}^{\mathrm{b}} \mathrm{PA}_{224^{-}}$and TRBV19+ D $^{\text {b PB1-F2 }}{ }_{62}$-specific sets are more diverse and demonstrate little overlap $(25,31)$. These profiles were also found for the naive TCRs, with the $\mathrm{D}^{\mathrm{b}} \mathrm{NP}_{366}$-specific CTLps exhibiting a degree of TCR clonotype sharing similar to that seen following antigen challenge (Table 1 ), while neither the naive $\mathrm{D}^{\mathrm{b}} \mathrm{PA}_{224^{-}}$or $\mathrm{D}^{\mathrm{b}} \mathrm{PB} 1-\mathrm{F} 2_{62-}$ specific TRBV repertoires showed significant overlap among individuals (Supplemental Tables 1 and 2 ). Thus, the public or private nature of any given antigen-driven immune repertoire is likely to reflect CTLp availability in the naive pool.

To further ascertain whether the relatively high frequency and "public" nature of particular CDR3 $\beta$-defined clonotypes in immune individuals may, indeed, be partly explained by their availability in naive populations (36), we analyzed both the immune and the naive repertoires to determine the prevalence of commonly shared $\mathrm{D}^{\mathrm{b}} \mathrm{NP}_{366^{-}}, \mathrm{D}^{\mathrm{b}} \mathrm{PA}_{224^{-}}$, and $\mathrm{D}^{\mathrm{b}} \mathrm{PB} 1-\mathrm{F} 2_{62}$-specific TCR- $\beta$ sequences (defined as being present in $33 \%$ or more of immune repertoires) within the dominant TRBV populations. The majority of the "shared" TCR clonotypes found in the immune, antigenspecific CTL sets were also detected at least once in uninfected mice (Supplemental Table 3). However, the most abundant clonotypes in the $\mathrm{D}^{\mathrm{b}} \mathrm{NP}_{366}, \mathrm{D}^{\mathrm{b}} \mathrm{PA}_{224}$, and $\mathrm{D}^{\mathrm{b}} \mathrm{PB} 1-\mathrm{F} 2_{62}$ immune repertoires contributed more substantially to the overall population than the most abundant clonotypes in the naive repertoire (Table 2). Thus, when considering dominant, public clonotypes within a particular 


\begin{tabular}{|c|c|c|c|c|c|c|}
\hline $\operatorname{CDR3} \beta$ & M1 & M2 & M3 & M4 & M5 & M6 \\
\hline SGGANTGQL & 3 & 3 & - & 3 & 2 & 3 \\
\hline SGGGNTGQL & 1 & - & - & - & - & 5 \\
\hline RGGANTGQL & - & 1 & 1 & 1 & 1 & 1 \\
\hline SGGSNTGQL & 1 & - & 1 & - & 1 & - \\
\hline KGGSNTGQL & 2 & - & - & - & - & - \\
\hline KAGGNTGQL & 1 & - & - & - & - & - \\
\hline KGGANTGQL & 1 & - & - & - & - & - \\
\hline KGGGNTGQL & 1 & - & - & - & - & - \\
\hline SDAWGAYEQ & 1 & - & - & - & - & - \\
\hline SGGARTGQL & 1 & - & - & - & - & - \\
\hline SDSRNTEV & - & 1 & - & - & - & - \\
\hline RGGSNTGQL & - & - & 1 & - & - & - \\
\hline SDAGVSYEQ & - & - & 1 & - & - & - \\
\hline KGGARTGQL & - & - & - & 1 & - & - \\
\hline SEGQGAEGAETL & - & - & - & 1 & - & - \\
\hline REGTEV & - & - & - & - & 1 & - \\
\hline SDGASAETL & - & - & - & - & - & 1 \\
\hline SGTGRSGNTL & - & - & - & - & - & 1 \\
\hline Total & 12 & 5 & 4 & 6 & 5 & 11 \\
\hline
\end{tabular}

mRNA from individual sorted cells isolated from pooled $L N$ and spleen of naive B6 mice was reverse transcribed followed by 2 rounds of nested TRBV13-1-specific PCR amplification. The PCR products were purified and TCR CDR3 regions sequenced using the internal TRBV13-1 oligonucleotide primer.

immune response, at least some of that profile appears to reflect that multiple T cells bearing the same TCR- $\beta$ (by aa sequence) are present prior to any encounter with antigen. Additionally, our data suggest that the ultimate, antigen-driven clone size is also likely to reflect the preferential selection of those TCRs with optimal pMHCI-binding characteristics into the immune repertoire (37).

Comparison of detected and estimated CTLp frequencies. Using singlecell PCR (31), we compared the number of TCR- $\beta$ aa signatures found in individual naive and immune antigen-specific CTL repertoires (Table 3). Surprisingly, for the dominant $\mathrm{D}^{\mathrm{b}} \mathrm{NP}_{366^{-}}$and $\mathrm{D}^{\mathrm{b}} \mathrm{PA}_{224}$-specific populations, more CDR3 $\beta$ clonotypes were found in the immune versus the naive repertoire (Table 3). Clearly, while the sampling procedure (14) provides a "best estimate" of naive CTLp diversity, analyzing the relatively small numbers that can be recovered significantly underestimates (by a factor of at least 1.6) the actual precursor diversity. This likely reflects the cell loss that is the inevitable consequence of the demanding enrichment protocol, together with the exclusion of minor LNs and tissue-associated lymphoid elements from the analysis. Aligning the naive and immune repertoires thus gives the sense that, when antigen is present, these immunodominant responses utilize every available CTLp in the naive pool.

Conversely, for the subdominant $\mathrm{D}^{\mathrm{b}} \mathrm{PB} 1-\mathrm{F} 2{ }_{62}$-specific repertoire, the numbers of different clonotypes found in naive populations were significantly larger (Table 3 ) than those recovered from the immune repertoire (43.6 and 32.0, respectively; $P=0.03$ ). Given the equivalent capacity of each tetramer to bind its specific population (Figure 1B and Supplemental Figure 1) and assuming the greater than or equal to 1.6 sampling underestimate of the naive $\mathrm{T}$ cell pool that we arrived at for the $\mathrm{D}^{\mathrm{b}} \mathrm{NP}_{366^{-}}$and $\mathrm{D}^{\mathrm{b}} \mathrm{PA}_{224}$-specific sets, it seems that only about a third of the naive $\mathrm{D}^{\mathrm{b} P B} 1-\mathrm{F} 2_{62}$ specific population made the transition to immune CTL status. This in turn suggests that the subdominant character of the $\mathrm{D}^{\mathrm{b}} \mathrm{PB} 1-\mathrm{F} 2_{62}$-specific CTL response reflects the incomplete recruitment of naive $\mathrm{T}$ cells into the mature response, while exactly the opposite is the case for the immunodominant $\mathrm{D}^{\mathrm{b}} \mathrm{NP}_{366}$ - and $\mathrm{D}^{\mathrm{b}} \mathrm{PA}_{224}$-specific populations. As related in the supplemental data (Supplemental Figure 4), this analysis was confirmed by Chao 1 nonparametric statistical analysis (38).

Immunodominance as a function of CTLp recruitment and expansion. The extent of naive CTLp recruitment into the primary influenza virus-specific CTL response was further analyzed by providing BrdU in the drinking water over 2-day intervals (days 3-4 or 5-6), then sampling on the third day (days 5,7 ) to analyze for BrdU incorporation as a measure of CTL cycling (Figure 3). By day 5, the majority of the $\mathrm{D}^{\mathrm{b}} \mathrm{NP}_{366^{-}}$and $\mathrm{D}^{\mathrm{b}} \mathrm{PA}_{224}$-specific CTLs were $\mathrm{CD} 44^{\mathrm{hi}} \mathrm{BrdU}{ }^{+}$, indicating that the corresponding naive CTLp pools were completely recruited to proliferate and become differentiated CTLs (Figure 3, A and B). However, only $35 \%$ of the $\mathrm{D}^{\mathrm{b}} \mathrm{PB} 1-\mathrm{F} 2_{62^{-}}$ specific set was $\mathrm{CD} 44 \mathrm{hiBrd}^{+}$at this time point (Figure $3 \mathrm{C}$ ), with approximately $50 \%$ still showing the $\mathrm{CD}_{4} 4^{\mathrm{lo}} \mathrm{BrdU} \mathrm{U}^{-}$phenotype of naive, undivided CTLps. Clearly, as predicted from the clonotypic analysis (Table 3 and Supplemental Figure 4), there is incomplete recruitment of the naive $\mathrm{D}^{\mathrm{b}} \mathrm{PB} 1-\mathrm{F} 2{ }_{62}$-specific precursors into this early phase of the immune response. Kinetic analysis of $\mathrm{D}^{\mathrm{b}} \mathrm{PB} 1-\mathrm{F} 2_{62}$ and $\mathrm{D}^{\mathrm{b}} \mathrm{NP}_{366}$ epitope presentation over time after i.n. influenza infection reveals that the overall level of $\mathrm{D}^{\mathrm{b}} \mathrm{PB} 1-\mathrm{F} 2_{62}$ was substantially less than $\mathrm{D}^{\mathrm{b}} \mathrm{NP}_{366}$ and peaked earlier, providing a likely mechanism for incomplete CTLp recruitment (Supplemental Figure 5). Looking at the other subdominant response (to $\mathrm{K}^{\mathrm{b} N S} 2_{114}$ ), the vast majority of tetramer ${ }^{+} \mathrm{T}$ cells were $\mathrm{CD} 44^{\mathrm{hi}} \mathrm{BrdU}^{+}$(Figure 3D) by day 5 after infection, indicating that, as far as the recruitment of naive CTLps is concerned, there is no difference between the subdominant $\mathrm{K}^{\mathrm{b} N S} 2_{114^{-}}$-specific and the immunodominant $\mathrm{D}^{\mathrm{b}} \mathrm{NP}_{366^{-}}$and $\mathrm{D}^{\mathrm{b}} \mathrm{PA}_{224^{-}}$-specific populations. The same conclusions can be drawn from the analysis of CTL cycling and differentiation profiles over the 5 to 6 day interval after respiratory exposure (Figure 3, E-H). Thus, differential mobilization from the naive CTLp pool (Figure 3, A-C) is not the sole explanation for the observed variations in primary CTL response magnitude. Importantly, these data also demonstrate, at

\section{Table 2}

Prevalence of the 1 or 2 most dominant clonotypes in naive and immune repertoires

\begin{tabular}{lcccc} 
& \multicolumn{2}{c}{ Top 1 } & \multicolumn{2}{c}{ Top 2 } \\
& Naive & Immune & Naive & Immune \\
$D^{\mathrm{b} N P_{366}}$ & $0.41 \pm 0.14^{\mathrm{A}}$ & $0.60 \pm 0.19$ & $0.62 \pm 0.14^{\mathrm{A}}$ & $0.82 \pm 0.12$ \\
$\mathrm{D}^{\mathrm{b} P A_{224}}$ & $0.13 \pm 0.08^{\mathrm{A}}$ & $0.24 \pm 0.09$ & $0.21 \pm 0.08^{\mathrm{A}}$ & $0.37 \pm 0.10$ \\
$\mathrm{D}^{\mathrm{b} P B 1-\mathrm{F} 2}{ }_{62}$ & $0.05 \pm 0.008^{\mathrm{A}}$ & $0.24 \pm 0.14$ & $0.08 \pm 0.02^{\mathrm{A}}$ & $0.35 \pm 0.16$
\end{tabular}

mRNA from individual sorted cells isolated from pooled $L N$ and spleen of naive $B 6$ mice was reverse transcribed followed by 2 rounds of nested TRBV-specific PCR amplification. The PCR products were purified and TCR CDR3 regions sequenced using the internal TRBV oligonucleotide primer. Values represent the contribution of the most abundant (top 1) or 2 most abundant (top 2) aa clonotypes to the total sequenced population. Data from $6\left(\mathrm{D}^{\mathrm{b}} \mathrm{NP}_{366}, \mathrm{D}^{\left.\mathrm{b} P A_{224}\right)}\right.$ or $5\left(\mathrm{D}^{\mathrm{b} P B 1}-\mathrm{F} 2_{62}\right)$ naive mice. Data from $11\left(\mathrm{D}^{\mathrm{b} N P_{366}}\right), 13\left(\mathrm{D}^{\mathrm{b} P A_{224}}\right)$, or 19 immune mice

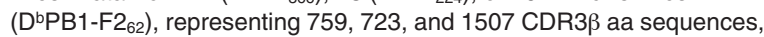
respectively. ${ }^{A} P \leq 0.01$, using unpaired Student's $t$ test. 
Table 3

Number of TCR CDR3 $\beta$ clonotypes per mouse

\begin{tabular}{|c|c|c|}
\hline & \multicolumn{2}{|c|}{ Number of clonotypes per mouse } \\
\hline & Naive & Immune \\
\hline $\mathrm{D}^{\mathrm{b} N P_{366}}$ & $4.8 \pm 2.1$ & $7.6 \pm 3.2$ \\
\hline $\mathrm{D}^{\mathrm{b} P A_{224}}$ & $15.3 \pm 3.3$ & $21.8 \pm 4.3$ \\
\hline$D^{\mathrm{b} P B} 1-\mathrm{F} 262$ & $43.6 \pm 12.3^{A}$ & $32.0 \pm 8.2$ \\
\hline \multicolumn{3}{|c|}{$\begin{array}{l}\text { mRNA from individual sorted cells isolated from pooled } L N \text { and spleen } \\
\text { of naive } B 6 \text { mice was reverse transcribed followed by } 2 \text { rounds of } \\
\text { nested TRBV-specific PCR amplification. The PCR products were puri- } \\
\text { fied and TCR CDR3 regions sequenced using the internal TRBV oligo- } \\
\text { nucleotide primer. Data from } 6\left(D^{b} N P_{366}, D^{b} P A_{224}\right) \text { or } 5\left(D^{b} P B 1-F 22_{62}\right) \\
\text { naive mice. Data from } 11\left(D^{b} N P_{366}\right), 13\left(D^{b} P A_{224}\right) \text {, or } 8\left(D^{b} P B 1-F 262\right) \\
\text { immune mice, representing } 759,723 \text {, and } 1012 \text { CDR3 } 3 \text { aa sequences, } \\
\text { respectively. }{ }^{A} P=0.03 \text {, comparing naive to immune clonotypes using a } \\
1 \text {-tailed, unpaired Student's } t \text { test. }\end{array}$} \\
\hline
\end{tabular}

least for $\mathrm{D}^{\mathrm{b}} \mathrm{NP}_{366}, \mathrm{D}^{\mathrm{b}} \mathrm{PA}_{224}$, and $\mathrm{K}^{\mathrm{b}} \mathrm{NS} 2_{114}$, that the CTLps detected within naive animals are true precursors in that they are virtually all capable of being drawn into the immune response.

It thus seems that, while the incomplete recruitment of naive CTLps may explain the subdominant status of the D ${ }^{\mathrm{b} B} 1$ $\mathrm{F} 2{ }_{62}$-specific response, it does not account for the comparably minor status of the $\mathrm{CD} 8^{+} \mathrm{K}^{\mathrm{b} N S} 2_{114^{+}}$set. Given that we can now enumerate naive CTLp numbers, it is also possible to estimate the overall extent of antigen-driven clonal expansion for the different CTL sets in this T cell immunodominance hierarchy. We measured total tetramer ${ }^{+} \mathrm{CD}^{+} \mathrm{T}$ cell numbers in pooled secondary lymphoid tissue taken at days 5, 7, and 9 after primary infection and calculated the fold expansion (Figure 4A) by relating the $\mathrm{CD} 8^{+} \mathrm{D}^{\mathrm{b}} \mathrm{NP}_{366^{+}}$, $\mathrm{CD} 8^{+} \mathrm{D}^{\mathrm{b}} \mathrm{PA}_{224^{+}}, \mathrm{CD} 8^{+} \mathrm{D}^{\mathrm{b}} \mathrm{PB} 1-\mathrm{F} 2_{62}{ }^{+}$, and $\mathrm{CD}^{+} \mathrm{K}^{\mathrm{b}} \mathrm{NS} 22_{114^{+}} \mathrm{T}$ cell counts to naive CTLP prevalence (Figure 1C). Despite evidence of proliferation at day 5 after infection, CTLP numbers in secondary lymphoid organs were minimally increased, likely reflecting the migration of early effector CTL to the infected lung. By day 7 , however, the magnitude of the $\mathrm{CD} 8^{+} \mathrm{D}^{\mathrm{b}} \mathrm{NP}_{366^{+}}$and $\mathrm{CD} 8^{+} \mathrm{D}^{\mathrm{b}} \mathrm{PA}_{224^{+}}$sets had increased 30 times or more while the comparable values for the subdominant $\mathrm{K}^{\mathrm{b}} \mathrm{NS} 2_{114^{-}}$and $\mathrm{D}^{\mathrm{b}} \mathrm{PB} 1-\mathrm{F} 2_{62}$-specific responses were $\times 8$ and $\times 2$ respectively (Figure 4A). Over the subsequent 2 days, the immunodominant $\mathrm{D}^{\mathrm{b}} \mathrm{NP}_{366^{-}}$and $\mathrm{D}^{\mathrm{b}} \mathrm{PA}_{224}$-specific CTLs expanded a further 120-130 times, while, despite the minimal early proliferation, the $\mathrm{CD} 8^{+} \mathrm{D}^{\mathrm{b} B \mathrm{~PB}} 1-\mathrm{F} 2{ }_{62}{ }^{+}$set increased 50 times, being 10 -fold higher than the $\times 5$ value for the $\mathrm{K}^{\mathrm{b} N S} 2_{114}$-specific response. Overall, the levels of expansion for the subdominant responses were approximately $\times 40\left(\mathrm{~K}^{\mathrm{b}} \mathrm{NS} 2_{114}\right)$ and $\times 100\left(\mathrm{D}^{\mathrm{b}} \mathrm{PB} 1-\mathrm{F} 2_{62}\right)$ compared with the approximate $\times 3,500$ increase for the immunodominant $\mathrm{D}^{\mathrm{b}} \mathrm{NP}_{366^{-}}$and $\mathrm{D}^{\mathrm{b}} \mathrm{PA}_{224}$-specific CTL sets.

\section{Figure 3}

Poor recruitment of CTLp specific for 1 subdominant epitope. B6 mice were infected i.n. with influenza A virus and given BrdU in the drinking water at days 3 and 4 or days 5 and 6 after infection. Cells from spleen and major LNs were harvested the next day (day 5, panels A-D; day 7, panels $\mathbf{E}-\mathbf{H}$ ), enriched with specific tetramers, and analyzed for BrdU incorporation and CD44 expression. Shown are representative dot plots from a group of 5 individual mice with the proportion of $\mathrm{CD}^{+}{ }^{\mathrm{C}} \mathrm{CD}{ }^{+} \mathrm{CD} 4-\mathrm{B} 220^{-} \mathrm{IA} \mathrm{A}^{\mathrm{b}} \mathrm{F} 4 / 80^{-}$tetramer ${ }^{+}$cells shown for each quadrant. Data are representative of 2 independent experiments.
An alternative approach for measuring continued CTL expansion is to "pulse" with BrdU, then "chase" to see how this DNA label is diluted with elapsed time (39). Mice were fed BrdU through days 3 to 5 after infection (pulse) and individuals were sampled on day 6 to confirm the extent of BrdU uptake or on day 7 or day 8 (chase) to estimate the rate of division-dependent loss (Figure 4B). The proportion of BrdU'tetramer ${ }^{+}$CTLs looked fairly similar for the 4 epitopes at the end of the pulse though, as might be expected from the values in Figure 4A, the extent of $\mathrm{BrdU}$ incorporation may have been a little lower for the $\mathrm{K}^{\mathrm{b}} \mathrm{NS} 2_{114^{-}}$ specific set (day 6; Figure 4B), indicative of reduced expansion. Thereafter, $\mathrm{BrdU}^{+}$tetramer ${ }^{+} \mathrm{CTL}$ frequencies remained highest for the subdominant $\mathrm{CD} 8^{+} \mathrm{D}^{\mathrm{b}} \mathrm{PB} 1-\mathrm{F} 2_{62}{ }^{+}$and $\mathrm{CD} 8^{+} \mathrm{K}^{\mathrm{b}} \mathrm{NS} 2_{114^{+}}$populations, further establishing that any continued cycling is at a lower level than that found for the immunodominant $\mathrm{CD} 8^{+} \mathrm{D}^{\mathrm{b}} \mathrm{NP}_{366^{+}}$ and $\mathrm{CD} 8^{+} \mathrm{D}^{\mathrm{b}} \mathrm{PA}_{224^{+}} \mathrm{T}$ cells (Figure 4B). Interestingly, considering the slightly poorer initial labeling of $\mathrm{K}^{\mathrm{b} N S} 2_{114}$-specific cells, the retention of a larger proportion of $\mathrm{BrdU}^{+}$cells at day 8 suggests that this population proliferates the least of all the 4 epitope-specific CTL populations (Figure 4B), likely explaining its subdominant status despite comprehensive CTLp recruitment.

Analysis of CD44 expression by naive CTLps. A recent study showed that a significant proportion (10\%-30\%) of epitope-specific CTLps recovered from naive animals were CD44hi, a phenotype typical of antigen-experienced cells or cells that have undergone homeostatic proliferation (40). As might be expected, these CD44hi cells showed

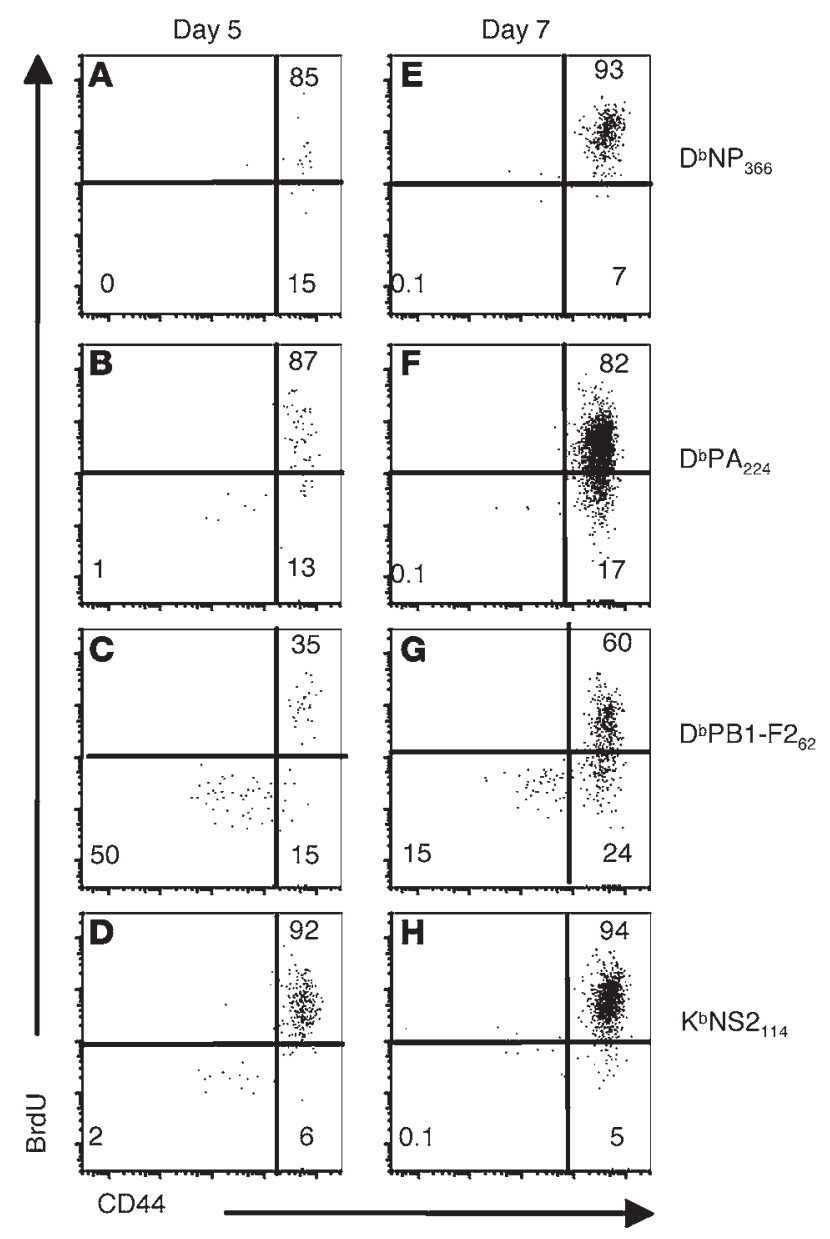


A

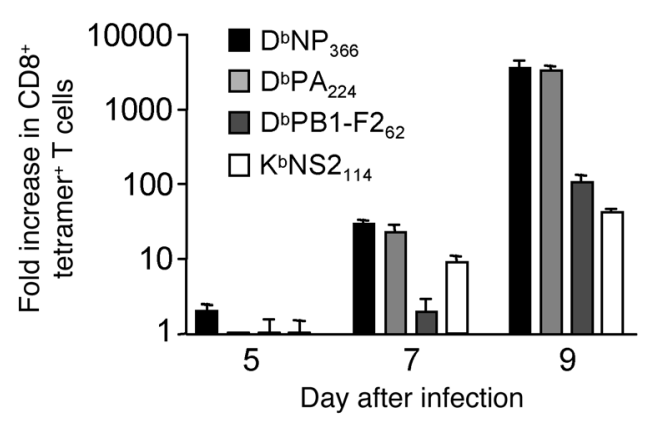

B

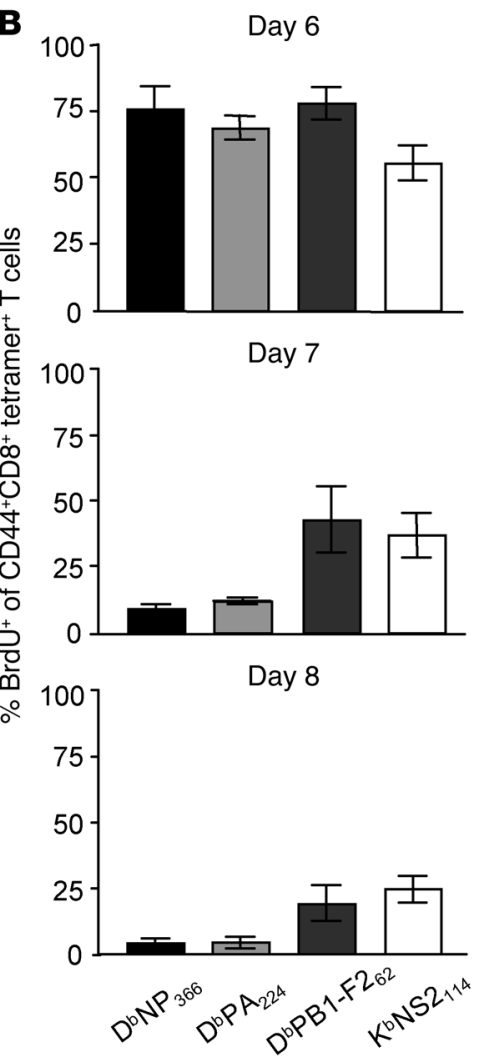

\section{Figure 4}

Reduced proliferation of subdominant epitope-specific CTLs late in infection. (A) B6 mice were infected i.n. with influenza $A$ virus and total cell tetramer cell numbers determined at days 5,7 , and 9 after infection. The fold expansion was determined by dividing the total number of CD8+tetramer ${ }^{+}$CTL at each time point by the average number of naive CTLps identified from Figure 1. Data represent 5 mice per tetramer, per time point. Shown is the fold difference \pm SD on a $\log _{10}$ scale. (B) $B 6$ mice were infected i.n. with influenza $A$ virus and fed BrdU in their drinking water on days 3-5 after infection. Cells from spleen and major LNs were harvested at the end of the BrdU treatment on day 6 , day 7 , or day 8 , enriched with specific tetramers, and analyzed for BrdU incorporation and CD44 expression. Shown is the mean proportion $\pm \mathrm{SD}$ ( $n=5$ mice per group) of CD44+tetramer+BrdU+ CTL present for each epitope specificity. Data are representative of 2 independent experiments. enhanced functional responsiveness to antigen stimulation when compared with the CD $44^{\text {lo }}$ subset. Therefore, it was formally possible that the differences in CTLp recruitment and expansion we observed here arose as a consequence of differential expression of CD44 among the epitope-specific populations. This is particularly relevant given that our gating strategy would certainly have included both the CD $44^{\text {hi }}$ and CD $44^{\text {lo }}$ subsets (Supplemental Figure 6). Analysis of CD44 expression on each of the 4 influenza epitope-specific CTLp populations identified from naive mice showed that all groups had similar proportions of CD $44^{\text {hi }}$ cells (Figure 5), with the only significant difference being that the naive $\mathrm{D}^{\mathrm{b}} \mathrm{NP}_{366^{-}}$ specific population (one of the most comprehensively recruited specificities) was least likely to be CD44hi. Thus, the differential expression of CD44 on naive CTLps is unlikely to account for the observed differences in recruitment and/or expansion among these epitope-specific populations.

\section{Discussion}

While naive antigen-specific CTLp frequency has long been considered a key determinant of the very reproducible CTL immunodominance hierarchies that emerge following primary infection $(6-8,26)$, there had, until very recently, been no direct evidence to support this view. The findings published so far from the use of improved pMHCI-tetramer enrichment protocols have uniformly supported the view that this interpretation is indeed correct and even suggest that CTL immune response magnitude is dictated by naive CTLp prevalence (14-16). Now, by looking concurrently at a spectrum of immunodominant and subdominant CTL populations induced by respiratory infection with the same influenza A virus, we have found that, rather than being a function of limited naive CTLp availability, the subdominant characteristic of 2 different pMHCI-specific sets was determined by differences in recruitment and/or ongoing proliferation through the course of the primary host response.

The numbers of naive, influenza A virus-specific CTLps that we detect in $\mathrm{B} 6$ mice fall within the range of both direct and indirect estimates of naive CTLp prevalence for other systems $(7,14,15$, 41). Our finding that the naive $\mathrm{CD} 8^{+} \mathrm{D}^{\mathrm{b}} \mathrm{PA}_{224^{+}}$and $\mathrm{CD} 8^{+} \mathrm{D}^{\mathrm{b}} \mathrm{NP}_{366}{ }^{+}$ CTLp counts differed by a factor of about 2 -fold confirmed a previous estimate based on looking at the extent of TCR CDR3 $\beta$ diversity and analyzing the early kinetics of these 2 responses $(10,26)$. These data also explain why transferring limiting numbers of naive B6 T cells into influenza A virus-infected $\mathrm{Rag}^{-1}-\mathrm{B} 6$ mice (27) led to the loss of the $\mathrm{D}^{\mathrm{b}} \mathrm{NP}_{366}$ - but not the $\mathrm{D}^{\mathrm{b}} \mathrm{PA}_{224}$-specific response.

For all studies that have made use of the tetramer-based enrichment technique to determine naive CTLp frequencies, a key question is whether every cell detected in this manner can respond to antigen. This is particularly relevant in the current study where there is significant discordance between naive CTLp numbers and subsequent immune response magnitudes. Significantly, our tracking data demonstrate that virtually all $\mathrm{K}^{\mathrm{b}} \mathrm{NS} 2{ }_{114}$-specific cells incorporate BrdU and upregulate CD44, both of which can be regarded as evidence of recruitment into an immune response. Thus, we know that discordance between "real" naive CTLp frequencies and immune magnitudes exists. As discussed later, the incomplete recruitment of naive $\mathrm{D}^{\mathrm{b}} \mathrm{PB} 1-\mathrm{F} 2{ }_{62}$-specific CTLps is likely to reflect the timing and extent of PMHCI expression rather than an inherent inability to be recruited. We have attempted to further address this question using a variety of in vivo immunization and in vitro stimulation experiments and have found variable 


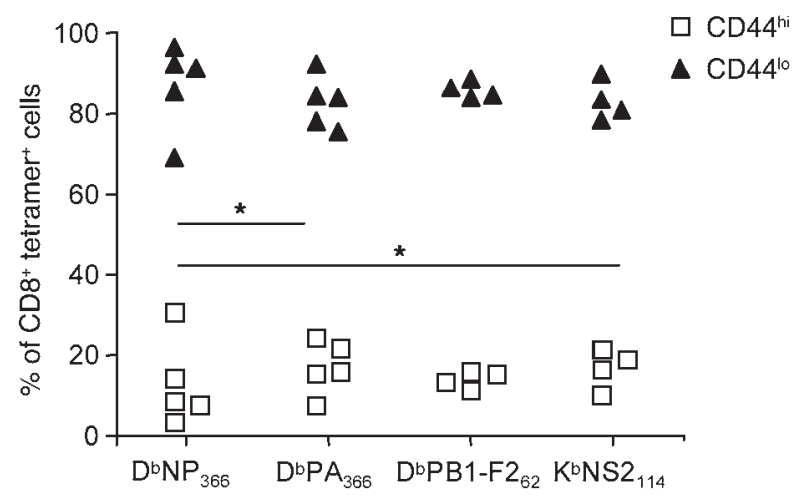

Figure 5

Expression of CD44 on epitope-specific CTLps from naive mice. Epitope-specific CTLps were identified from naive mice as described in legend to Figure 1. The proportion of CD44hi or CD44/o epitope-specific CTLps are shown. Symbols represent data from individual mice. ${ }^{\star} P<0.05$ using Student's $t$ test with Bonferroni's correction.

response magnitudes that do not correlate with either naive CTLP frequencies or response magnitudes after infection. The implications of these data are unclear and are the subject of further study, but leave open the possibility that CTLps may vary in their capacity to respond to antigen. In any case, our data do not support the contention that naive CTLp frequencies detected in this way are predictive of immune magnitudes after infection.

Statistical evaluation indicates that the naive CTLp numbers generated in these experiments underestimate (by at least $\times 1.6$ ) the total size of the potentially available pool in unprimed individuals. The difference from earlier studies $(14,15)$ that inferred incomplete sampling is that the acuity of the current analysis is enhanced by the comparison of CDR $3 \beta$-defined clonotype profiles in the naive CTLp and immune CTL pools. The antigen-driven immune response samples the whole mouse, not just the pooled LNs and spleen that are taken for naive CTLp enrichment. Furthermore, apart from the exclusion of blood, bone marrow, and mucosal-associated lymphoid tissue, some $\mathrm{T}$ cells will inevitably be lost during the technical procedure. Even so, the fact that the naive CTLp counts were both consistent from experiment to experiment and sufficiently reproducible to allow careful statistical analysis provides reassurance that the efficiency of the tetramer enrichment protocol is equivalent for the different pMHCI epitopes. In addition, the fidelity of the tetramer enrichment procedure is evidenced by negligible tetramer binding in OTI TCR Tg mice and canonical TCR CDR3 $\beta$ sequences observed in naive repertoires.

It is very clear from the present analysis that the nature of immune TCR repertoires specific for a range of different $\mathrm{pMH}$ CIs is determined directly by the naive, "preantigen" CTLp repertoire. Earlier experiments showed that CD8 ${ }^{+} \mathrm{TRBV} 13-1^{+} \mathrm{D}^{\mathrm{b}} \mathrm{NP}_{366}{ }^{+}$ immune CTLs demonstrate a high degree of "public" TCR- $\beta$ sharing among individuals $(30,36,42)$, but the $\mathrm{CD} 8^{+} \mathrm{TRBV} 29^{+} \mathrm{D}^{\mathrm{b}} \mathrm{PA}_{224^{+}}$ and $\mathrm{CD} 8^{+} \mathrm{TRBV} 19^{+} \mathrm{D}^{\mathrm{b}} \mathrm{PB} 1-\mathrm{F} 2{ }_{62}{ }^{+}$sets are characterized by more "private" profiles with relatively little overlap in TCR- $\beta$ sequence $(25,31)$. Single-cell CDR3 $\beta$ sequence analysis of naive $\mathrm{D}^{\mathrm{b}} \mathrm{NP}_{366^{-}}$ and $\mathrm{D}^{\mathrm{b}} \mathrm{PA}_{224}$-specific CTLps established that, while the dominance of particular TCR clonotypes within individuals differs from the naive to the immune repertoires, this degree of clonotype shar- ing between individuals does not. Thus, the "public" or "private" nature of immune repertoires reflects the comparable characteristics of the naive CTLp pools. In addition, the preferred TRBV biases observed for $\mathrm{D}^{\mathrm{b}} \mathrm{NP}_{366^{-}}, \mathrm{D}^{\mathrm{b}} \mathrm{PA}_{224^{-}}, \mathrm{D}^{\mathrm{b}} \mathrm{PB} 1-\mathrm{F} 2_{62^{-}}$, and $\mathrm{K}^{\mathrm{b}} \mathrm{NS} 2_{114^{-}}$ specific immune repertoires were also evident for the naive CTLps. Both for the $\mathrm{D}^{\mathrm{b}} \mathrm{NP}_{366^{-}}$and $\mathrm{D}^{\mathrm{b}} \mathrm{PA}_{224}$-specific CTL responses there was, however, evidence of narrowed TRBV bias from the naive to the immune repertoires. A limited analysis of the TRBV29+ $\mathrm{K}^{\mathrm{b} N S} 2_{114}$-specific immune and naive repertoires was also performed (Supplemental Table 4). While not sufficiently intensive to allow comment on the degree of naive clonotype recruitment, the analysis does illustrate the nature of the naive and immune TRBV29+ $\mathrm{K}^{\mathrm{b} N S} 2_{114^{-}}$specific repertoires. The naive repertoire was typically diverse, with only 2 of 33 clonotypes repeated in 4 mice (and one of these was distinct at the nucleotide level). Interestingly, however, the immune repertoire showed a distinct hierarchy with a dominant clonotype apparent in both the immune repertoires analyzed. These data support the notion of selective clonotype expansion within the TRBV29+ $\mathrm{K}^{\mathrm{b} N S} 2_{114}$-specific population. Previous studies with TCR Tg T cells indicate that such selection reflects differing TCR avidity profiles $(37,43)$. As such, enrichment of TRBV bias from the naive into the immune repertoire is presumably due to the preferential selection/proliferation of CTLps with "optimal-fit" TCRs $(37,43,44)$.

The clonotypic analysis of naive and immune $\mathrm{D}^{\mathrm{b}} \mathrm{PB} 1-\mathrm{F} 2{ }_{62}-\mathrm{spe}-$ cific TCRs indicated that, unlike the situation for $\mathrm{D}^{\mathrm{b}} \mathrm{NP}_{366}$ and $\mathrm{D}^{\mathrm{b}} \mathrm{PA}_{224}$, there is incomplete recruitment from the naive into the immune repertoire, providing a likely explanation for $\mathrm{D}^{\mathrm{b}} \mathrm{PB} 1-\mathrm{F} 2_{62}$ subdominance. Recruitment of naive CTLps into the immune repertoire requires that naive precursors must overcome a TCR-mediated signaling threshold that, once reached, will ensure the survival of a particular $\mathrm{T}$ cell through recruitment and sustained clonal expansion $(37,45)$. As such, it is tempting to speculate that all the available naive $\mathrm{D}^{\mathrm{b}} \mathrm{NP}_{366^{-}}$and $\mathrm{D}^{\mathrm{b}} \mathrm{PA}_{224}$-specific CTLps are capable of overcoming this threshold, ensuring complete recruitment. In contrast, it is possible that, despite a wide array of TCR clonotypes, only a proportion of the $\mathrm{D}^{\mathrm{b}} \mathrm{PB} 1-\mathrm{F} 2_{62}$ repertoire are able to cross the line and be selected into the immune repertoire.

The alternative explanation for the observed pMHCI-related differences in CTLp recruitment from the naive repertoire and subsequent patterns of clonal expansion is, of course, that these $\mathrm{T}$ cell responses are "measuring" differences in both the magnitude and duration of antigen load. The PB1-F2 protein is expressed late, has a relatively short half-life, is not incorporated into maturing virions, and is not required for virus production $(21,46)$. Furthermore, promoting rapid virus/APC clearance effectively abrogates the $D^{\text {bPB1-F2 }}{ }_{62}$-specific response without modifying the initial profiles or $\mathrm{D}^{\mathrm{b}} \mathrm{NP}_{366^{-}}$or $\mathrm{D}^{\mathrm{b}} \mathrm{PA}_{224^{-}}$-specific CTL expansion, suggesting that the in vivo presentation of $\mathrm{D}^{\mathrm{b}} \mathrm{PB} 1-\mathrm{F} 2{ }_{62}$ is substantially delayed relative to $\mathrm{D}^{\mathrm{b}} \mathrm{NP}_{366}$ and $\mathrm{D}^{\mathrm{b}} \mathrm{PA}_{224}$ (47). Similarly, when the infectious process is prolonged as a consequence of disrupting the $\mathrm{NP}_{366}$ and $\mathrm{PA}_{224}$ peptides within the challenge virus, the $\mathrm{D}^{\mathrm{b}} \mathrm{PB} 1-\mathrm{F} 2_{62}$ specific response increases in magnitude $(48,49)$. The subdominant character of the $\mathrm{D}^{\mathrm{b}} \mathrm{PB} 1-\mathrm{F} 2_{62}$-specific expansion, together with the more limited recruitment from the naive repertoire, may simply reflect this profile of delayed and diminished antigen expression (Supplemental Figure 5). We have shown previously for $\mathrm{D}^{\mathrm{b}} \mathrm{NP}_{366}$ and $\mathrm{D}^{\mathrm{b}} \mathrm{PA}_{224}$ that varying the protein context (and thus the abundance) of an immunogenic peptide can modify primary response magnitude (26). 
The situation for the other subdominant epitope ( $\left.\mathrm{K}^{\mathrm{b} N S} 2_{114}\right)$ was very different with the combination of BrdU and CD44 phenotype analysis indicating that, though the $\mathrm{K}^{\mathrm{b} N S} 2_{114}$-specific CTLps were completely recruited, they were unable to sustain a proliferative response through the course of the infection. Again, this profile may reflect the relative timing and magnitude of antigen load. The NS2 protein plays a key part early in viral replication by ensuring the nuclear export of viral ribonucleoproteins (50) and the regulation of viral transcription (51). Furthermore, while NS2 may be incorporated in the virion, the amount of NS2 is minimal compared with NP and PA (52). Thus, in contrast to the delayed antigen expression observed for the PB1-F2 protein, high levels of available NS2 $2_{114}$ peptide are likely to be present early after infection and diminish quickly, potentially explaining the full recruitment of $\mathrm{K}^{\mathrm{b} N S} 2_{114}$-specific naive CTLps and their failure to sustain expansion over the later stages of the response.

Taken together, the findings from the present analysis of naive CTLp prevalence and utilization demonstrate that the fundamental character of the naive TCR repertoire is reflected in the immune compartment and that subdominant responses may represent both a failure to fully recruit the naive precursor pool and an inability to sustain proliferative responses. Thus, there is cause for optimism that the parameter of naive CTLp frequency, which we are unable to change for any given PMHCI complex, may not be the major limitation when it comes to generating robust CTL responses. These findings have important implications for designing vaccines aimed at promoting the magnitude and breadth of what are normally "minor" responses. This, in turn, may be advantageous for efficient viral clearance as well as the prevention of viral escape (4, $5,53)$. The same arguments may apply to tumor immunity.

\section{Methods}

Mice and tissue harvesting. Female $\mathrm{B} 6\left(\mathrm{H} 2^{\mathrm{b}}\right)$ mice were bred and housed in the animal facility of the Department of Microbiology and Immunology at the University of Melbourne. All experimental procedures were reviewed and approved by the University of Melbourne Animal Experimentation Ethics Committee. For analysis of naive epitope-specific $\mathrm{CD}^{+} \mathrm{T}$ cell populations, spleen and LNs (axillary, brachial, mesenteric, cervical, and inguinal) were dissected from individual naive mice, pooled, and single-cell suspensions produced by pushing through nylon mesh. For analysis of primary CTL responses, naive 6-8 week old mice were infected i.n. with $1 \times 10^{4} \mathrm{PFU}$ of the HKx31 influenza A virus. For analysis of CTL at 7, 8, or 10 days after infection, single-cell preparations of spleen were enriched for $\mathrm{CD} 8^{+}$cells by panning for 1 hour at $37^{\circ} \mathrm{C}$ on plates coated with a mixture of anti-mouse IgG/IgM (Jackson Laboratories).

Enrichment and isolation of low numbers of epitope-specific CTLs. For identification and isolation of influenza virus epitope-specific $\mathrm{CD} 8^{+} \mathrm{T}$ cells present in naive animals, we modified a previously described magnetic enrichment and flow cytometric technique for the identification of naive $\mathrm{CD} 4^{+}$cells (14). Spleen and LN cells were resuspended in Fc block (spent 24G2 supernatant $/ 0.5 \%$ mouse serum $/ 0.5 \%$ rat serum) with $\mathrm{PE}$-conjugated tetrameric complexes of the influenza virus $\mathrm{H}-2 \mathrm{D}^{\mathrm{b}}$ or $\mathrm{H}-2 \mathrm{~K}^{\mathrm{b}} \mathrm{MHC}$ class I glycoprotein and the $\mathrm{NP}_{366-374}$ (ASNENMETM), PA 224-233 (SSLENFRAYV), PB1-F2 $62-70$ (LSLRNPILV), or NS2 ${ }_{114-121}$ (RTFSFQLI) peptides $(5 \mu \mathrm{g} / \mathrm{ml})$ and incubated at room temperature for 1 hour. Cells were then washed once with cold sorter buffer (PBS/0.5\% BSA $/ 2 \mathrm{mM}$ EDTA), then resuspended in $400 \mu \mathrm{l} \mathrm{buf-}$ fer plus $100 \mu \mathrm{l}$ anti-PE microbeads (Miltenyi Biotech) and incubated at $4{ }^{\circ} \mathrm{C}$ for 20-30 minutes. Cells were washed twice in sorter buffer, resuspended in $3 \mathrm{ml}$ buffer, and passed over an LS magnetic column (Miltenyi Biotech) according to manufacturer's instructions. The initial flow-through was passed over the column twice, followed by $3 \times 3 \mathrm{ml}$ washes with buffer. The column was then removed from the magnet and bound cells eluted by pushing $5 \mathrm{ml}$ of sorter buffer through column. The eluted cells were then incubated for 30 minutes at $4{ }^{\circ} \mathrm{C}$ with a cocktail of antibodies as follows: either (a) anti-CD8 $\alpha$-APC-Cy7, anti-CD3e-PerCP-Cy5.5, anti-CD4-PE-Cy7, antiCD62L- or anti-CD44-APC, and anti-B220/F4/80/CD11c/CD11b-FITC, or (b) anti-CD8 $\alpha$-APC-Cy7, anti-CD3e-PerCP-Cy5.5, anti-CD4-PE-Cy7, anti-B220/F4/80/CD11c/CD11b-APC, and one of anti-VB8.3(TRBV13-1)/ anti-V $\beta 7$ (TRBV29)/anti-V $\beta 6$ (TRBV19)-FITC. Both cocktails were designed for the exclusion of cells that have nonspecifically bound tetramer as well as identification of epitope-specific $\mathrm{CD}^{+}{ }^{+}$cells (tetramer ${ }^{+} \mathrm{CD}^{+} \mathrm{CD}^{+}{ }^{+} \mathrm{B} 220^{-}$ $\left.\mathrm{F} 4 / 80^{-} \mathrm{CD} 11 \mathrm{c}^{-} \mathrm{CD} 11 \mathrm{~b}^{-} \mathrm{CD}^{-}\right)$. The second cocktail was used to determine the $\mathrm{V} \beta$ bias in naive epitope-specific $\mathrm{CD}^{+} \mathrm{T}$ cell populations. Cells were finally washed and the entire sample (including 2 rinses of the sample tube) was run on a BD LSR II or FACSCanto II flow cytometer or sorted on a FACSAria high-speed cell sorter. Figure 1, B and C, shows the total number of naive epitope-specific CTLps from each mouse identified following this procedure.

Determination of naive CTLp frequency. Total epitope-specific CTLps from the spleen and all major LNs of naive B6 mice were enumerated after enrichment with the various tetramers, as described above. Prior to magnetic enrichment, $\mathrm{CD}^{+} \mathrm{T}$ cell number within the sample was determined by total cell count and flow cytometric determination of percentage of $\mathrm{CD} 8^{+}$cells $\left(\mathrm{CD}^{+} \mathrm{T}\right.$ cell number $=\% \mathrm{CD}^{+}$cells $\times$total cell count). Frequency of naive CTLps was then determined using the following equation: (naive CTLp frequency $=$ (number of naive CTLps detected/CD8 ${ }^{+} \mathrm{T}$ cell number $\left.) \times 10^{6}\right)($ Supplemental Figure 2$)$.

Tetramer and antibody staining of acute phase cells. Epitope-specific $\mathrm{CD}^{+} \mathrm{T}$ cells at or near the acute stage of the response (days $7,8,10$ ) were identified using tetramer staining. Cells were incubated with $\mathrm{D}^{\mathrm{b}} \mathrm{NP}_{366}-\mathrm{PE}, \mathrm{D}^{\mathrm{b}} \mathrm{PA}_{224}-\mathrm{PE}, \mathrm{D}^{\mathrm{b}} \mathrm{PB1}$ $\mathrm{F} 2_{62}-\mathrm{PE}$, or $\mathrm{K}^{\mathrm{b}} \mathrm{NS}_{114}-\mathrm{PE}$ tetramers for 1 hour at room temperature, washed, and stained with anti-CD8 $\alpha$-FITC or anti-CD8 $\alpha$-APC with a combination of FITC-conjugated anti-B220/F4/80/CD11b/CD11c Abs. Cells were washed, and the staining profiles were analyzed using a BD FACSCalibur.

Stimulation and ICS. Stimulation and ICS of cells from immune mice has been described (54). Briefly, enriched lymphocytes from spleen and BAL were stimulated in vitro for 5 hours with $10 \mathrm{U} / \mathrm{ml} \mathrm{IL-2} \mathrm{in} \mathrm{the} \mathrm{presence} \mathrm{or} \mathrm{absence}$ of $1 \mu \mathrm{M}$ peptide. They were then stained for cell-surface expression of CD8 $\alpha$ and intracellular expression of IFN- $\gamma$ and analyzed by flow cytometry.

Analysis of BrdU incorporation. Naive B6 mice were infected i.n. and received $\operatorname{BrdU}(0.8 \mathrm{mg} / \mathrm{ml})$ in their drinking water over 2-day intervals (days 3-4 or days 5-6) followed by sampling on the third day (days 5, 7) to analyze BrdU incorporation as a snapshot of CTL cycling. Alternatively, infected mice were given $\mathrm{BrdU}$ in the drinking water through days 3-5 after infection (pulse) and sampled on day 6 (to confirm the extent of BrdU uptake), day 7 , or day 8 (chase) to estimate the rate of division-dependent loss. For both protocols, spleen and LN cells (including the mediastinal LN) were harvested and epitope-specific cells were identified following magnetic enrichment as described. Following infection, antibodies specific for the following cell surface proteins were used: CD8, CD3, CD44, CD4, B220, F4/80. Antibodies specific for CD11b and $\mathrm{CD} 11 \mathrm{c}$ were excluded since they may be expressed by activated $\mathrm{CD} 8^{+} \mathrm{T}$ cells. Intracellular staining for $\mathrm{BrdU}$ was then performed according to the protocol outlined in the BrdU Flow Kit (BD Pharmingen).

Kinetic analysis of $D^{b} N P_{366}$ and $D^{b} P B 1-F 2_{62}$ epitope presentation. MLN cells $\left(\sim 1 \times 10^{4}\right)$ were cocultured in 96 -well plates with $2 \times 10^{4} \mathrm{D}^{\mathrm{b}} \mathrm{NP}_{366}$ or $\mathrm{D}^{\mathrm{b}} \mathrm{PB} 1$ F2 62 -specific hybridoma cells (4-39, F2-54, respectively) for 24 hours. These hybridoma lines only produce IL-2 when exposed to their cognate peptides (55). At the same time, a standard curve was generated using peptide-pulsed, uninfected splenocytes. This also showed similar peptide sensitivities of the hybridomas to their respective peptides (not shown). Secreted IL- 2 was measured by ELISA using purified anti-IL-2 and biotin 
anti-IL-2 (BD) antibodies according to manufacturer's directions (BD Biosciences). Epitope concentrations were calculated from the standard curve and the amount of IL-2 produced.

Analysis of epitope-specific $T$ cell repertoires. Individual $\mathrm{CD}^{+} \mathrm{D}^{\mathrm{b}} \mathrm{NP}_{366^{+}}$, $\mathrm{D}^{\mathrm{b}} \mathrm{PA}_{224^{+}}, \mathrm{D}^{\mathrm{b} P B 1}-\mathrm{F}_{62}{ }^{+}$, or $\mathrm{K}^{\mathrm{b}} \mathrm{NS} 2{ }_{114^{+}}$cells were sorted from naive spleens and LNs, mRNA was reverse transcribed as described (31), and a nested PCR strategy $(25,30,31)$ was used to amplify TRBV13-1 ( $\left.D^{\text {b }} \mathrm{NP}_{366}\right)$, TRBV29 $\left(D^{b} \mathrm{PA}_{224}, K^{\mathrm{b} N S} 2_{114}\right)$, or TRBV19 (D $\left.{ }^{\mathrm{b} B} 1-\mathrm{F} 2_{62}\right)$ cDNA using V $\beta$-specific oligonucleotide primers. Second-round TRBV PCR products were then purified using the QIAquick PCR Purification Kit (QIAGEN), sequenced using $3.2 \mathrm{pmol}$ of the internal TRBV-specific primer and analyzed on an ABI Prism 3700 sequence analyzer. In some instances, the cDNA was split into 2 samples for concurrent RT-PCR analysis of CD8 expression (56) for calculation of TRBV frequencies. Naive epitope-specific $T$ cell repertoires were compared with published immune TCR sequence databases for $\mathrm{D}^{\mathrm{b}} \mathrm{NP}_{366}$ (30), $\mathrm{D}^{\mathrm{b} P A_{224}}$ (31), or $\mathrm{D}^{\mathrm{b} P B 1-F 2}{ }_{62}(25)$.

Statistics. The Mann-Whitney $U$ test or Student's 2-tailed (unless otherwise stated) unpaired $t$ test (with Bonferroni's correction for multiple comparisons) was used to determine significance for all individual statistical comparisons, with the exception of the Chao1. For calculations of Chao1, we used EstimateS v 7.51 (57).

1. Yewdell JW, Bennink JR. Immunodominance in major histocompatibility complex class I-restricted T lymphocyte responses. Annu Rev Immunol. 1999; 17:51-88.

2. Frahm N, et al. Control of human immunodeficiency virus replication by cytotoxic $\mathrm{T}$ lymphocytes targeting subdominant epitopes. Nat Immunol. 2006;7(2):173-178.

3. Thomas PG, et al. Hidden epitopes emerge in secondary influenza virus-specific $\mathrm{CD}^{+} \mathrm{T}$ cell responses. J Immunol. 2007;178(5):3091-3098.

4. Price DA, et al. T cell receptor recognition motifs govern immune escape patterns in acute SIV infection. Immunity. 2004;21(6):793-803.

5. Sacre K, et al. Repertoire, diversity, and differentiation of specific CD8 T cells are associated with immune protection against human cytomegalovirus disease. J Exp Med. 2005;201(12):1999-2010.

6. Chen W, Anton LC, Bennink JR, Yewdell JW. Dissecting the multifactorial causes of immunodominance in class I-restricted $\mathrm{T}$ cell responses to viruses. Immunity. 2000;12(1):83-93.

7. Blattman JN, et al. Estimating the precursor frequency of naive antigen-specific CD8 T cells. J Exp Med. 2002;195(5):657-664.

8 . Bousso $\mathrm{P}$, et al. Individual variations in the murine $\mathrm{T}$ cell response to a specific peptide reflect variability in naive repertoires. Immunity. 1998;9(2):169-178

9. Butz EA, Bevan MJ. Massive expansion of antigenspecific $\mathrm{CD}^{+} \mathrm{T}$ cells during an acute virus infection. Immunity. 1998;8(2):167-175.

10. Kedzierska K, et al. Quantification of repertoire diversity of influenza-specific epitopes with predominant public or private TCR usage. J Immunol. 2006;177(10):6705-6712.

11. McHeyzer-Williams MG, Davis MM. Antigen-specific development of primary and memory T cells in vivo. Science. 1995;268(5207):106-111.

12. Pewe LL, Netland JM, Heard SB, Perlman S. Very diverse CD8 $\mathrm{T}$ cell clonotypic responses after virus infections. J Immunol. 2004;172(5):3151-3156.

13. Whitmire JK, Benning N, Whitton JL. Precursor frequency, nonlinear proliferation, and functional maturation of virus-specific CD4+ T cells. JImmunol. 2006;176(5):3028-3036.

14. Moon JJ, et al. Naive CD4(+) T cell frequency varies for different epitopes and predicts repertoire diversity and response magnitude. Immunity. 2007;27(2):203-213.

\section{Acknowledgments}

We thank D. Godfrey, F. Carbone, W. Heath, and K. Shortman for reagents and J. Rossjohn for critical review of the manuscript. This work was supported by National Health and Medical Research Council (NHMRC) project grants AI454595 (to N.L. La Gruta and P.C. Doherty) and AI454312 (to K. Kedzierska), NHMRC Program grant (AI567122 to P.C. Doherty), NIH grants AI70251 (to P.C. Doherty) and AI065097 (to P.G. Thomas), NHMRC RD Wright Career Development Awards (to N.L. La Gruta and K. Kedzierska), a Pfizer Australia Research Fellowship (to S.J. Turner), an NHMRC Biomedical Postgraduate Scholarship (ID520643 to T. Cukalac), and an Australian-American Fulbright Postgraduate Scholarship (to W.T. Rothwell).

Received for publication October 22, 2009, and accepted in revised form March 10, 2010.

Address correspondence to: Nicole L. La Gruta, Department of Microbiology and Immunology, University of Melbourne, Parkville, Victoria 3010, Australia. Phone: 61.3.8344.7962; Fax: 61.3.9347.1540; E-mail: nllg@unimelb.edu.au.
15. Obar JJ, Khanna KM, Lefrancois L. Endogenous naive $\mathrm{CD} 8^{+} \mathrm{T}$ cell precursor frequency regulates primary and memory responses to infection. Immunity. 2008;28(6):859-869.

16. Kotturi MF, et al. Naive precursor frequencies and MHC binding rather than the degree of epitope diversity shape $\mathrm{CD8}^{+} \mathrm{T}$ cell immunodominance. J Immunol. 2008;181(3):2124-2133.

17. van Heijst JW, et al. Recruitment of antigen-specific $\mathrm{CD8}^{+} \mathrm{T}$ cells in response to infection is markedly efficient. Science. 2009;325(5945):1265-1269.

18. Chen W, Bennink JR, Morton PA, Yewdell JW. Mice deficient in perforin, CD4+ T cells, or CD28-mediated signaling maintain the typical immunodominance hierarchies of $\mathrm{CD}^{+} \mathrm{T}$-cell responses to influenza virus. J Virol. 2002;76(20):10332-10337.

19. Townsend AR, Rothbard J, Gotch FM, Bahadur G, Wraith D, McMichael AJ. The epitopes of influenza nucleoprotein recognized by cytotoxic T lymphocytes can be defined with short synthetic peptides. Cell. 1986;44(6):959-968.

20. Belz GT, Xie W, Altman JD, Doherty PC. A previously unrecognized $\mathrm{H}-2 \mathrm{D}(\mathrm{b})$-restricted peptide prominent in the primary influenza A virusspecific CD8(+) T-cell response is much less apparent following secondary challenge. $J$ Virol. 2000;74(8):3486-3493.

21. Chen W, et al. A novel influenza A virus mitochondrial protein that induces cell death. Nat Med. 2001;7(12):1306-1312.

22. Vitiello A, et al. Immunodominance analysis of CTL responses to influenza PR8 virus reveals two new dominant and subdominant Kb-restricted epitopes. J Immunol. 1996;157(12):5555-5562.

23. Kedzierska K, Venturi V, Field K, Davenport MP, Turner SJ, Doherty PC. Early establishment of diverse $\mathrm{T}$ cell receptor profiles for influenza-specific CD8(+)CD62L(hi) memory T cells. Proc Natl Acad Sci U S A. 2006;103(24):9184-9189.

24. Belz GT, Xie W, Doherty PC. Diversity of epitope and cytokine profiles for primary and secondary influenza a virus-specific $\mathrm{CD}^{+} \mathrm{T}$ cell responses. J Immunol. 2001;166(7):4627-4633.

25. La Gruta NL, et al. Epitope-specific TCRbeta repertoire diversity imparts no functional advantage on the $\mathrm{CD}^{+} \mathrm{T}$ cell response to cognate viral peptides. Proc Natl Acad Sci U S A. 2008;105(6):2034-2039.

26. La Gruta NL, et al. A virus-specific $\mathrm{CD}^{+} \mathrm{T}$ cell immunodominance hierarchy determined by anti- gen dose and precursor frequencies. Proc Natl Acad Sci US A. 2006;103(4):994-999.

27. Yager EJ, Ahmed M, Lanzer K, Randall TD, Woodland DL, Blackman MA. Age-associated decline in $T$ cell repertoire diversity leads to holes in the repertoire and impaired immunity to influenza virus. J Exp Med. 2008;205(3):711-723.

28. Chothia C, Boswell DR, Lesk AM. The outline structure of the T-cell alpha beta receptor. EMBO J. 1988;7(12):3745-3755.

29. Cabaniols JP, Fazilleau N, Casrouge A, Kourilsky P, Kanellopoulos JM. Most alpha/beta T cell receptor diversity is due to terminal deoxynucleotidyl transferase. J Exp Med. 2001;194(9):1385-1390.

30. Kedzierska K, Turner SJ, Doherty PC. Conserved $\mathrm{T}$ cell receptor usage in primary and recall responses to an immunodominant influenza virus nucleoprotein epitope. Proc Natl Acad Sci U S A. 2004;101(14):4942-4947.

31. Turner SJ, Diaz G, Cross R, Doherty PC. Analysis of clonotype distribution and persistence for an influenza virus-specific $\mathrm{CD}^{+} \mathrm{T}$ cell response. Immunity. 2003;18(4):549-559.

32. Lefranc MP, et al. IMGT, the international ImMunoGeneTics database. Nucleic Acids Res. 1999;27(1):209-212.

33. Deckhut AM, et al. Prominent usage of $\mathrm{V}$ beta $8.3 \mathrm{~T}$ cells in the H-2Db-restricted response to an influenza A virus nucleoprotein epitope. J Immunol. 1993;151(5):2658-2666.

34. Belz GT, Stevenson PG, Doherty PC. Contemporary analysis of $\mathrm{MHC}$-related immunodominance hierarchies in the $\mathrm{CD}^{+} \mathrm{T}$ cell response to influenza A viruses. J Immunol. 2000;165(5):2404-2409.

35. Zhong W, Reinherz EL. In vivo selection of a TCR Vbeta repertoire directed against an immunodominant influenza virus CTL epitope. Int Immunol. 2004;16(11):1549-1559.

36. Venturi V, et al. Sharing of $\mathrm{T}$ cell receptors in antigen-specific responses is driven by convergent recombination. Proc Natl Acad Sci U S A. 2006;103(49):18691-18696.

37. Malherbe L, Hausl C, Teyton L, McHeyzer-Williams MG. Clonal selection of helper T cells is determined by an affinity threshold with no further skewing of TCR binding properties. Immunity. 2004;21(5):669-679.

38. Shen TJ, Chao A, Lin JF. Predicting the number of new species in further taxonomic sampling. Ecology. 2003;84(3):798-804. 
39. Flynn KJ, Riberdy JM, Christensen JP, Altman JD, Doherty PC. In vivo proliferation of naive and memory influenza-specific CD8(+) T cells. Proc Natl Acad Sci U S A. 1999;96(15):8597-8602

40. Haluszczak C, et al. The antigen-specific $\mathrm{CD}^{+} \mathrm{T}$ cell repertoire in unimmunized mice includes memory phenotype cells bearing markers of homeostatic expansion. J Exp Med. 2009;206(2):435-448.

41. Badovinac VP, Haring JS, Harty JT. Initial T cell receptor transgenic cell precursor frequency dictates critical aspects of the CD8(+) T cell response to infection. Immunity. 2007;26(6):827-841.

42. Turner SJ, Doherty PC, McCluskey J, Rossjohn J. Structural determinants of T-cell receptor bias in immunity. Nat Rev Immunol. 2006;6(12):883-894.

43. McHeyzer-Williams LJ, Panus JF, Mikszta JA, McHeyzer-Williams MG. Evolution of antigenspecific $\mathrm{T}$ cell receptors in vivo: preimmune and antigen-driven selection of preferred complementarity-determining region 3 (CDR3) motifs. J Exp Med. 1999;189(11):1823-1838.

44. Kjer-Nielsen L, et al. A structural basis for the selection of dominant alphabeta $\mathrm{T}$ cell receptors in antiviral immunity. Immunity. 2003;18(1):53-64.

45. Zehn D, Lee SY, Bevan MJ. Complete but curtailed
T-cell response to very low-affinity antigen. Nature. 2009;458(7235):211-214.

46. Zamarin D, Ortigoza MB, Palese P. Influenza A virus $\mathrm{PB} 1-\mathrm{F} 2$ protein contributes to viral pathogenesis in mice. J Virol. 2006;80(16):7976-7983.

47. Thomas PG, Brown SA, Yue W, So J, Webby RJ, Doherty PC. An unexpected antibody response to an engineered influenza virus modifies $\mathrm{CD}^{+} \mathrm{T}$ cell responses. Proc Natl Acad Sci U S A. 2006;103(8):2764-2769.

48. Andreansky SS, Stambas J, Thomas PG, Xie W, Webby RJ, Doherty PC. Consequences of immunodominant epitope deletion for minor influenza virus-specific CD8 ${ }^{+}-\mathrm{T}$-cell responses. J Virol. 2005;79(7):4329-4339.

49. Webby RJ, et al. Protection and compensation in the influenza virus-specific $\mathrm{CD}^{+} \mathrm{T}$ cell response. Proc Natl Acad Sci US A. 2003;100(12):7235-7240.

50. O'Neill RE, Talon J, Palese P. The influenza virus NEP (NS2 protein) mediates the nuclear export of viral ribonucleoproteins. EMBO J. 1998;17(1):288-296.

51. Robb NC, Smith M, Vreede FT, Fodor E. NS2/NEP protein regulates transcription and replication of the influenza virus RNA genome. J Gen Virol. 2009;90(pt 6):1398-1407.

52. Richardson JC, Akkina RK. NS2 protein of influenza virus is found in purified virus and phosphorylated in infected cells. Arch Virol. 1991;116(1-4):69-80.

53. Messaoudi I, Guevara Patino JA, Dyall R, LeMaoult J, Nikolich-Zugich J. Direct link between mhc polymorphism, T cell avidity, and diversity in immune defense. Science. 2002;298(5599):1797-1800.

54. La Gruta NL, Turner SJ, Doherty PC. Hierarchies in cytokine expression profiles for acute and resolving influenza virus-specific $\mathrm{CD}^{+} \mathrm{T}$ cell responses: correlation of cytokine profile and TCR avidity. JImmunol. 2004;172(9):5553-5560.

55. Aldridge JR Jr. et al. TNF/iNOS-producing dendritic cells are the necessary evil of lethal influenza virus infection. Proc Natl Acad Sci U S A. 2009;106(13):5306-5311.

56. Jenkins MR, Kedzierska K, Doherty PC, Turner SJ. Heterogeneity of effector phenotype for acute phase and memory influenza A virus-specific CTL. JImmunol. 2007;179(1):64-70.

57. Colwell RK. EstimateS: statistical estimation of species richness and shared species from samples. Version 7.51 User's Guide and application published at: http://viceroy.eeb.uconn.edu/estimates. 2005. 